\title{
Influence of Micro and Macro Cracks Due to Sustained Loading on Chloride-Induced Corrosion of Reinforced Concrete Beams
}

\author{
Junjie Wang, Sreejith V. Nanukuttan, P. A. Muhammed Basheer \\ School of Planning, Architecture and Civil Engineering, Queen's University Belfast, Northern Ireland, UK. \\ Yun Bai \\ Department of Civil, Environmental \& Geomatic Engineering, University College London, UK.
}

\begin{abstract}
Chloride-induced corrosion of steel is one of the most commonly found problems affecting the durability of reinforced concrete structures in both marine environment and where de-icing salt is used in winter. As the significance of micro-cracks on chloride induced corrosion is not well documented, 24 reinforced concrete beams (4 different mixes - one containing Portland cement and another containing 35\% ground granulated blastfurnace slag at 0.45 and 0.65 water-binder ratios) were subjected to three levels of sustained lateral loading $(0 \%, 50 \%$ and $100 \%$ of the load that can induce $0.1 \mathrm{~mm}$ wide cracks on the tension surface of beam- $\mathrm{F}_{0.1}$ ) in this work. The beams were then subjected to weekly cycles of wetting with $10 \% \mathrm{NaCl}$ solution for 1 day followed by 6 days of drying at $20( \pm 1)^{\circ} \mathrm{C}$ up to an exposure period of 60 weeks. The progress of corrosion of steel was monitored using half-cell potential apparatus and linear polarisation resistance (LPR) test. These results have shown that macro-cracks (at load $\mathrm{F}_{0.1}$ ) and micro-cracks (at $50 \%$ of $\mathrm{F}_{0.1}$ ) greatly accelerated both the initiation and propagation stages of the corrosion of steel in the concrete beams. Lager crack widths for the $F_{0.1}$ load cases caused higher corrosion rates initially, but after about 38 weeks of exposure, there was a decrease in the rate of corrosion. However, such trends could not be found in $50 \% \mathrm{~F}_{0.1}$ group of beams. The extent of chloride ingress also was influenced by the load level. These findings suggest that the effect of micro-cracking at lower loads are very important for deciding the service life of reinforced concrete structures in chloride exposure environments.
\end{abstract}

\section{INTRODUCTION}

Reinforced concrete structures are subjected to various types of loads, which can lead to cracking when the tensile stress in concrete exceeds its tensile strength. Cracking could increase transport properties of concrete and accelerate the ingress of harmful substances $\left(\mathrm{Cl}^{-}, \mathrm{O}_{2}, \mathrm{H}_{2} \mathrm{O}, \mathrm{SO}_{3}, \mathrm{CO}_{2}\right.$ ) (Mehta \& Monterio, 2006). This could initiate and accelerate different types of deterioration processes in concrete, including corrosion of steel reinforcement. In fact, chloride-induced corrosion of steel in reinforced concrete structures is one of the main problems affecting their durability (Basheer et al., 1996) and this topic was studied extensively by many researchers for decades. However, most of them investigated the corrosion of steel in 'lab concrete', which was uncracked and not subjected to any structural loads (Bamforth, 2004; Violetta, 2002; Thomas \& Bentz, 2001; Siemes \& Edvardsen, 1999). Although a small proportion of them dealt with chloride induced corrosion in cracked concretes, the influence of cracks wider than $0.07 \mathrm{~mm}$, or even sometimes wider than $0.7 \mathrm{~mm}$, termed commonly as macro-cracks, was investigated (Sangoju et al., 2011; Otieno et al., 2008 \& 2010, Sahmaran, 2007; Rodriguez \& Hooton, 2003; Mohammed et al., 2001; Schiessl \& Raupach, 1997). In fact, the maximum crack width allowed in designing reinforced concrete is $0.3 \mathrm{~mm}$ in chloride-laden environment according to BS EN 1992-1-1:2004 (British Standards Institution, 2011a). Therefore, concrete elements in structures could have cracks of different sizes up to $0.3 \mathrm{~mm}$ due to the loading and, hence, there exist smaller cracks, termed as microcracks, which can influence the corrosion of steel in reinforced concrete elements exposed to chloride environments because chlorides can be transported through such cracks. Although a small number of publications dealt with the influence of micro-cracks (greater than $30 \mu \mathrm{m}$ ) (Wang et al., 2011; Wang et al., 2014; Li, 2000; Li et al., 2011; Sahmaran, 2007; Sahmaran \& Yaman, 2008; Konin et al., 1998), the significance of micro-cracks on chloride induced corrosion is not well documented. Therefore, it is necessary to investigate the effect of relatively small cracks, including microcracks, on the corrosion of steel in reinforced concrete that has been exposed to chlorides so that the number of premature failure of reinforced concrete structures could be reduced.

Therefore, an investigation was carried out, in which reinforced concrete beams were subjected to three different levels of loading and then exposed to a cyclic regime of chloride exposure under the sustained loading. The results were used to establish the effect of different load levels on both chloride penetration and 
chloride induced corrosion of steel in reinforced concrete elements.

\section{EXPERIMENTAL PROGRAMME}

As stated in the introduction, the objective of the research was to establish the influence of different levels of load that cause concrete to develop cracks up to a width of $0.1 \mathrm{~mm}$ on both the chloride penetration and chloride induced corrosion of steel in concrete. The experimental variables are reported in Table 1.

Table 1. Experimental variables.

\begin{tabular}{lll}
\hline Variables & \multicolumn{2}{l}{ Levels of variables } \\
\hline Type of cementitious & $100 \% \mathrm{CEMI}^{\star}$ & 65\% CEMI \\
material & (denoted as & $+35 \%$ GGBS \\
& CEMI) & (denoted as \\
& & GGBS)
\end{tabular}

Water-cementitious $\quad 0.45$

material ratio

Load level

50

100

Percentage of load

level that can induce

cracks of size up to

$\left.1 \mathrm{~mm}-\mathrm{F}_{0.1}\right)$

* CEMI-Portland cement containing at least 95\% of Portland cement clinker and conforming to BS EN 197-1:2011 (BSI, 2011b)

** GGBS-Ground granulated blastfurnace slag, conforming to BS EN 6699: 1992

Altogether there were 12 experimental combinations (2 cementitious materials $\times 2$ water-cementitious material ratios $x 3$ levels of applied load). The zero load level is meant to represent unloaded condition. A water-binder ratio of 0.45 was decided on the basis of what is considered to be a low value for concretes subjected to marine exposure conditions and a value of 0.65 was chosen to represent the highest allowed (British Standards Institution, 2012). Ground granulated blastfurnace (GGBS) complying with BS EN 6699: 1992 (British Standards Institution 1992) was used to replace Portland cement, CEMI, by $35 \%$ in two mixes. The proportions for each mix are reported in Table 2.

\begin{tabular}{lllll}
\multicolumn{6}{l}{ Table 2. Concrete mix } & proportions & $\left(\mathrm{kg} / \mathrm{m}^{3}\right)$. \\
\hline Mix ID & $\mathbf{0 . 4 5 -}$ & $\mathbf{0 . 4 5 -}$ & $\mathbf{0 . 6 5 -}$ & $\mathbf{0 . 6 5 -}$ \\
& CEMI & GGBS & CEMI & GGBS \\
\hline CEMI & 360 & 234 & 300 & 105 \\
GGBS & - & 126 & - & 195 \\
Water & 162 & 162 & 195 & 195 \\
Superplasticiser & 0.47 & 0.42 & - & - \\
Fine aggregate & 776 & 772 & 761 & 754 \\
$\begin{array}{l}\text { Coarse agg. } \\
\text { 5-10 mm }\end{array}$ & & & & \\
$10-20 \mathrm{~mm}$ & 384 & 382 & 376 & 373 \\
& 780 & 776 & 764 & 758 \\
\hline
\end{tabular}

\subsection{Materials}

As indicated in Table 1, Class $42.5 \mathrm{~N}$ CEMI conforming to BS EN 197-1:2011 and GGBS confirming to BS EN
6699: 1992 were used as the cementitious materials in this research. The coarse aggregate used was crushed and well graded basalt of size $5-20 \mathrm{~mm}$ (size 5-10 $\mathrm{mm}$ and $10-20 \mathrm{~mm}$ mixed in the ratio 1:2) and the fine aggregate was natural medium graded sand (BS EN 882: 1992). The aggregates were oven-dried at $100( \pm 5){ }^{\circ} \mathrm{C}$ for 24 hours to remove the initial moisture content, but the mix water content was adjusted by adding extra water to compensate for the aggregate absorption so as to ensure that the aggregates were in saturated surface dry condition at the time of mixing. The superplasticiser was polycarboxylate based, with a solid content of $29 \%$ in water. The water content of the mixes was adjusted to take account of the water introduced by the superplasticiser.

\subsection{Test specimens}

Six beams $(1200 \times 250 \times 200 \mathrm{~mm}$ in size $)$ and six 100 $\mathrm{mm}$ size cubes were cast for each mix. The reinforcement drawing of the beams is shown in Figure 1. As shown in this figure, the depth of cover was $25 \mathrm{~mm}$.

The required quantities of the mix constituents were batched by mass and then mixed using a pan mixer in accordance with BS 1881:125: 1986 (BSI, 1989). The workability of the mixes was determined using the slump test and the data for each mix is reported in Table 3. A vibrating table was used to compact concrete in the cubes and a poker vibrator was used to compact concrete in the beams. The top surface of the specimens was then finished with a trowel and a thick black polythene sheet was used to cover the surface. The cubes were demoulded after 24 hours and then placed in water bath at $20( \pm 1){ }^{\circ} \mathrm{C}$ for the next 3 days. They were then wrapped in wet hessian and thick polythene sheet. The beams were demoulded after 7 days and then wrapped in wet hessian and the thick polythene sheet. All specimens were then placed in a constant temperature room at $20( \pm 1)^{\circ} \mathrm{C}$.

\subsection{Tests carried out}

The compressive strength test was conducted on three cubes per mix at the age of 28 and 56 days and the results are reported in Table 3.

At the age of 56 days, two concrete beams of each mix were subjected to three loading levels $(0 \%, 50 \%$, and $100 \%$ of the load that can induce crack with a width of $0.1 \mathrm{~mm}$ on the tension surface of the beam$F_{0.1}$ ), as shown in Figures 1 and 2 . The intensity of load was kept constant during the test period by topping up the level, if needed, at every 20 weeks.

The tension face of all beams was subjected to weekly cycles of wetting (for 1 day) and drying (for 6 days) 
with chloride solution ( $10 \% \mathrm{NaCl}$ by weight) for 60 weeks. The ponding setup is shown in Figure 3. All faces except the tension faces were sealed with epoxy paint to ensure ingress of chloride ions through only the tension faces.
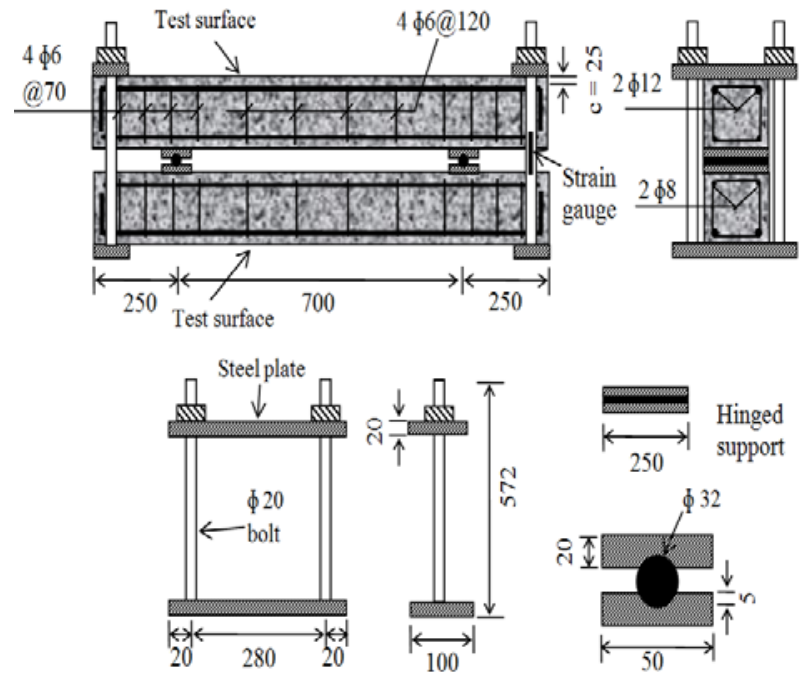

Figure 1. Schematic setup and reinforcement drawing.

Table 3. Physical properties of concrete.

\begin{tabular}{lclll}
\hline Mix ID & $\mathbf{0 . 4 5 C E M I}$ & $\begin{array}{l}\text { 0.45CEMI } \\
\text { 35\%GGBS }\end{array}$ & 0.65CEMI & $\begin{array}{l}\text { 0.65CEMI } \\
\text { 35\%GGBS }\end{array}$ \\
\hline $\begin{array}{l}\text { Slump } \\
(\mathrm{mm})\end{array}$ & 120.0 & 95.0 & 95.0 & 100.0 \\
$\mathrm{f}_{\mathrm{c}}$ 28d & 58.0 & 50.7 & 37.8 & 35.1 \\
$\begin{array}{l}\text { (MPa) } \\
\mathrm{f}_{\mathrm{c}} 56 \mathrm{~d} \\
(\mathrm{MPa})\end{array}$ & 59.5 & 56.7 & 38.7 & 48.9 \\
\hline
\end{tabular}

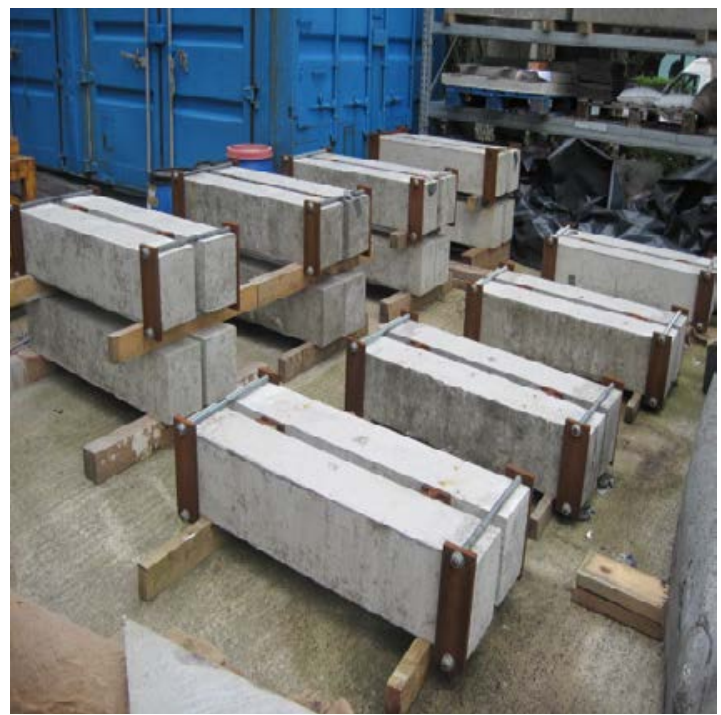

Figure 2. Test beams under sustained loading.
A Digital Half Cell (DHC) apparatus satisfying ASTM C876 (1999) was used to measure the potential of steel in the beam at every two weeks during the test period. The Linear Polarisation Resistance (LPR) method was used to test the rate of corrosion. As prewetting of the concrete surface was required for both these tests, particularly if the surface was dry, these tests were carried out just after the wetting phase of the cycles. The ambient temperature was also recorded at the time of each test.

Cell for ponding the chloride solution

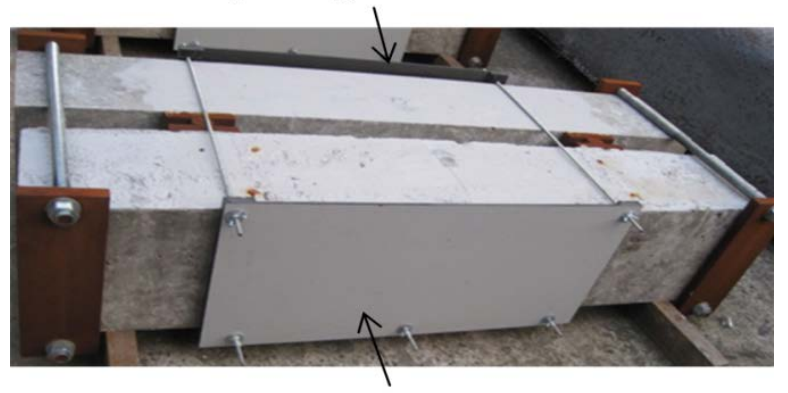

Cell for ponding the chloride solution

Figure 3. Setup for ponding cells.

At the end of 60 weeks of cyclic ponding with chloride solution, concrete dust samples were collected from different depths from the exposed surface by drilling using an $8 \mathrm{~mm}$ drill bit and analysed using potentiometric titration for determining the acid soluble chloride content. In the case of $F_{0.1}$ load cases where visible cracks were found, the chloride content was determined at both the cracked region and the region away from it.

\section{RESULTS AND DISCUSSION}

\subsection{Chloride profiles after 60 weeks of cyclic ponding}

The chloride profiles of beams at the three different load levels are presented in Figures $4 a$ to $4 d$ for the four different types of concrete mixes. In the case of $F_{0.1}$ beams, two profiles are included, one for the region where visible cracks were found and another for the region where there were no visible cracks. For all mixes, there was a flat profile at the region where there were visible cracks, indicating that cracks facilitated the penetration of chlorides to deeper parts of the beams. However, in all other cases, there was a sharp decrease in chloride content with depth. 


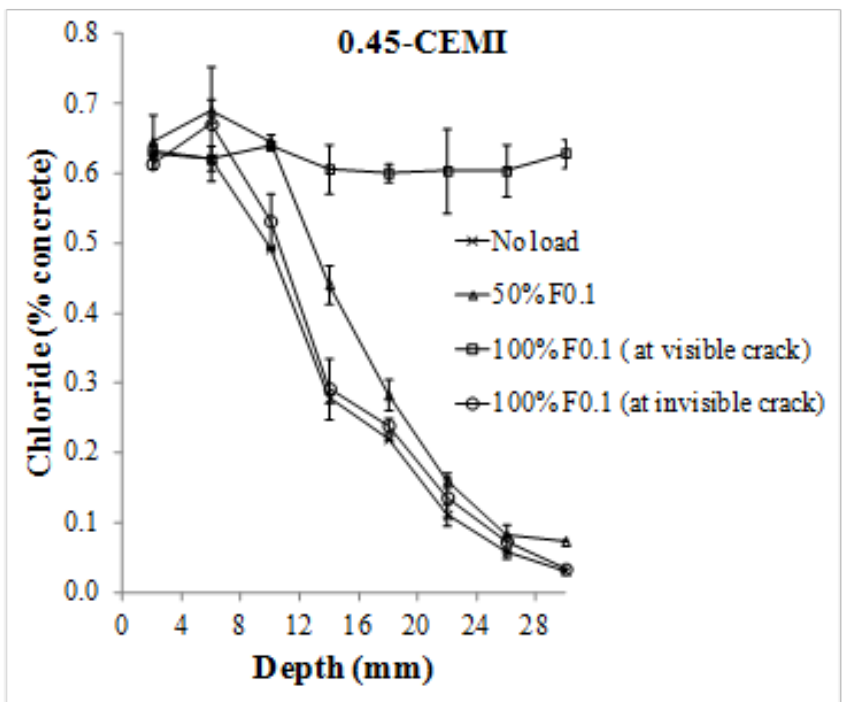

Figure 4a. Chloride profile for 0.45 CEMI beam.

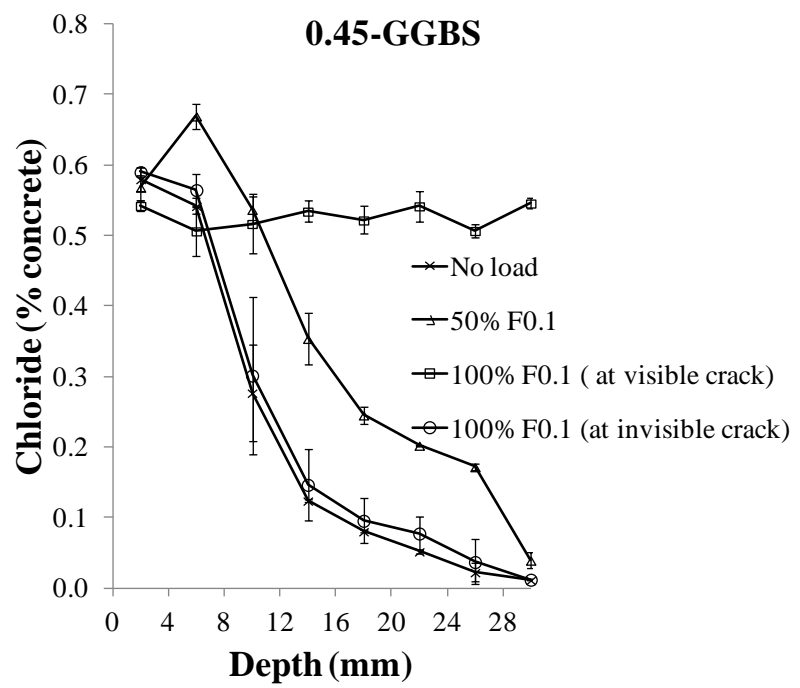

Figure 4b. Chloride profile for 0.45 GGBS beam.

A comparison of the three load cases in each diagram of Figure 4 would indicate that the chloride content was the lowest for the beams which were not subjected to any load for all the four mixes, as one would expect. Interestingly, the chloride content was higher in beams subjected to $50 \%$ of $\mathrm{F}_{0.1}$ load than in beams subjected to $100 \%$ of $F_{0.1}$ load at regions where there were no visible cracks. An increase in waterbinder ratio was found to increase the chloride content for both types of cementitious materials and the use of GGBS was found to decrease the chloride content in the beams, as one would expect. The chloride content in Figure 4 would suggest that all beams subjected to $100 \%$ of $F_{0.1}$ load would have severe corrosion. In other cases, only $0.65 \mathrm{CEMI}$ beams at all load cases and 0.45 GGBS beam subjected to $50 \%$ of $F_{0.1}$ load would have corrosion of steel that had a cover of 25 $\mathrm{mm}$.

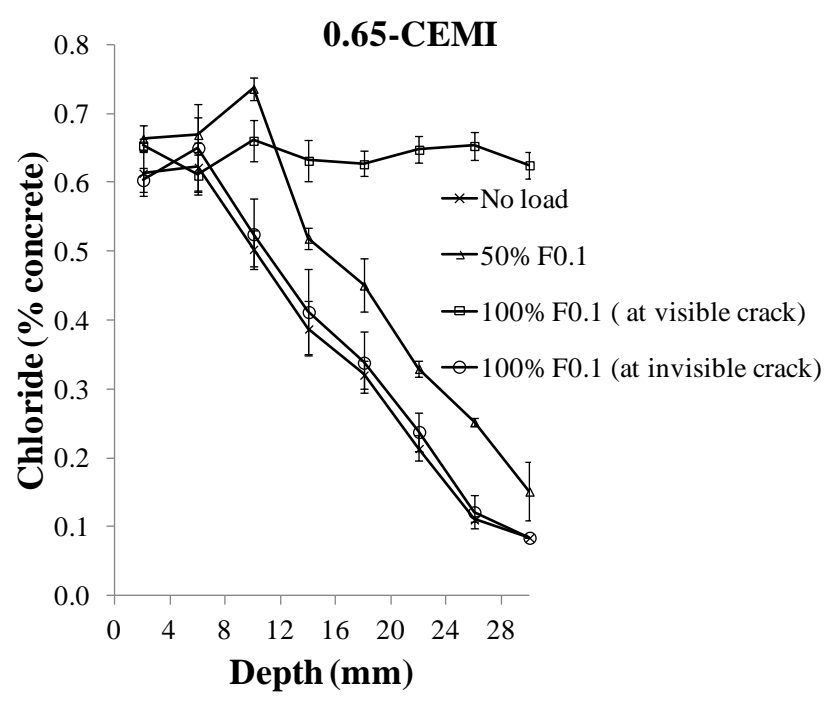

Figure 4c. Chloride profile for 0.65 CEMI beam.

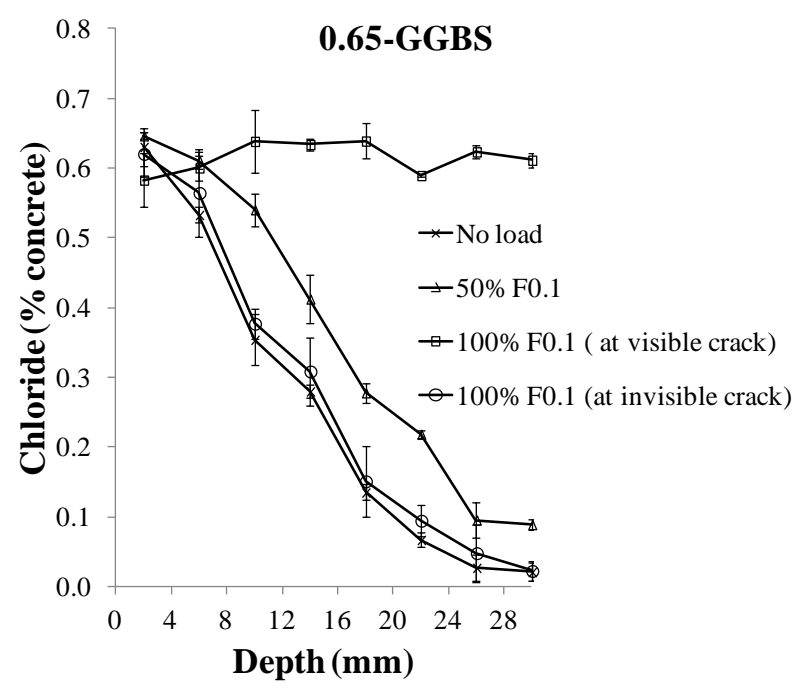

Figure 4d. Chloride profile for 0.65 GGBS beam.

\subsection{Half-cell potentials and rates of corrosion}

Both the half-cell potentials and corrosion currents were compensated for variations in temperature before they were used in any discussion.

As shown in Equation 1, the temperature coefficient is $-0.5 \mathrm{mV}$ per ${ }^{\circ} \mathrm{F}$ for the temperature range $32-120{ }^{\circ} \mathrm{F}(0$ to $\left.49^{\circ} \mathrm{C}\right)$ (ASTM C876-91).

$$
E_{0}=E+\left[(25-T) \times \frac{9}{5}+32\right] \times(-0.5)
$$

where $E_{0}$ is the half-cell potential at the reference temperature $25{ }^{\circ} \mathrm{C}$ (in $\mathrm{mV}$ ); $E$ is the half-cell potential measured at the temperature $T_{0}$ (in $\mathrm{mV}$ ); $T_{0}$ is the temperature of the concrete at measurement (in ${ }^{\circ} \mathrm{C}$ ).

The influence of temperature on the kinetics of electrode processes can be expressed by the 
Arrhenius relationship Equation 2 (C. Brett \& A. Brett, 1993).

$$
k=A e^{\frac{-Q}{R T}}
$$

where $\mathrm{k}$ is chemical reaction rate (in $\mathrm{s}^{-1}$ or $\mathrm{M}^{-1} \mathrm{~s}^{-1}$ ); $\mathrm{A}$ is a constant factor (in $\mathrm{s}^{-1}$ or $\mathrm{M}^{-1} \mathrm{~S}^{-1}$ ); $\mathrm{Q}$ is the activation energy (in $\mathrm{kJ} / \mathrm{mol}$ ); $e$ is the base of natural logarithm; $\mathrm{R}$ is the gas constant, $R=8.314 \mathrm{~J} / \mathrm{mol} \mathrm{K} ; \mathrm{T}$ is the absolute temperature in which the reaction takes place (in $\mathrm{K}$ ).

The temperature effect can thus be corrected by Equation 3 (Liu, 1996) to convert the measured values to the corrosion current at the reference temperature ( $25^{\circ} \mathrm{C}$ here).

$$
i_{0}=i e^{2283\left(\frac{1}{T}-\frac{1}{T_{0}}\right)}
$$

where $i_{0}$ is the corrosion current at the reference temperature $T_{0} ; i$ is the corrosion current measured at
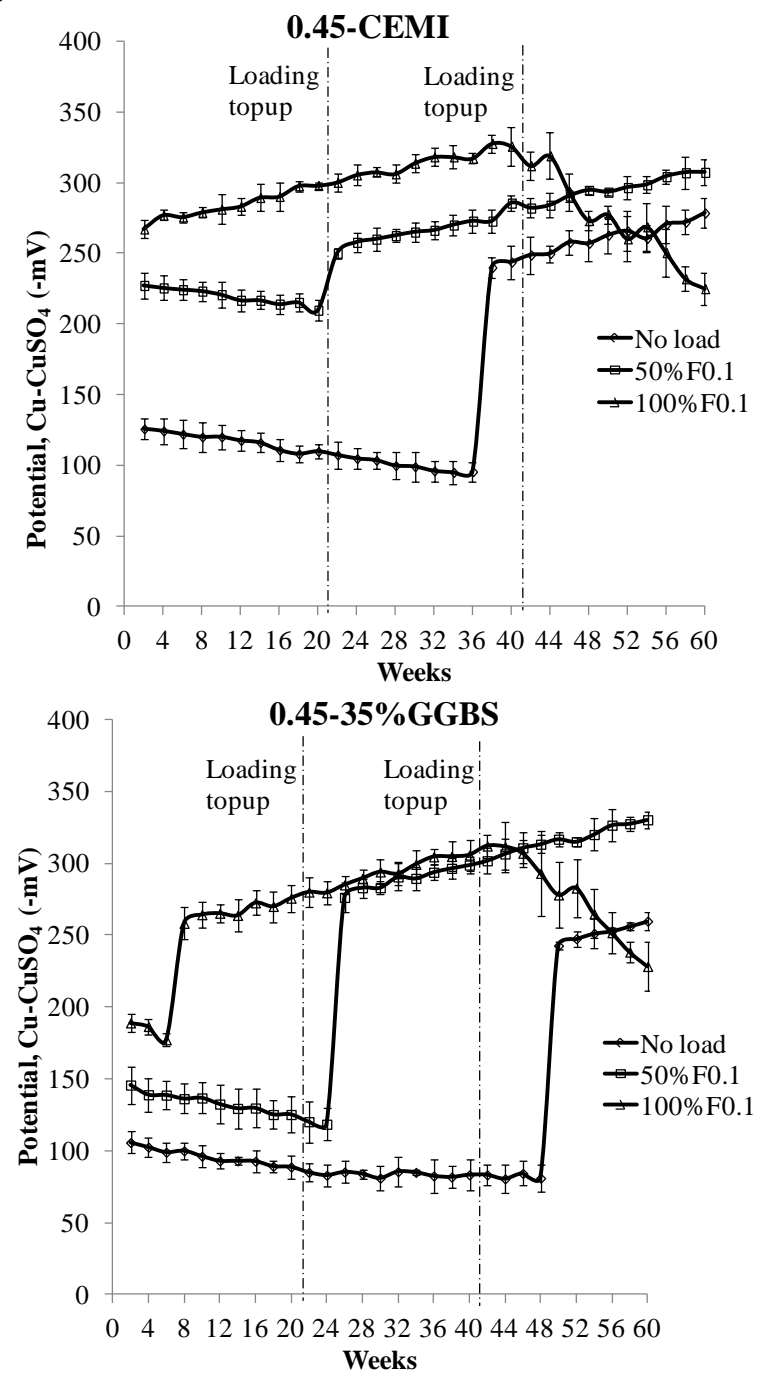

Figure 5. Temperature compensated half-cell potentials. temperature $T ; T$ is the absolute temperature of the concrete at the measurement; $T_{0}$ is the absolute temperature of the concrete at the measurement, $T_{0}=$ $273+25=298 \mathrm{~K}$.

Figures 5 and 6 show the temperature compensated corrosion potentials and corrosion current values. The data presented in these figures show that the effect of cyclic chloride ponding on chloride induced corrosion was similar for both the unloaded beams and beams subjected to $50 \%$ of $\mathrm{F}_{0.1}$ load, though there was a delay for the onset of corrosion for beams that were not loaded. However, there was a significant deviation from this trend for the beams subjected to $100 \%$ of $F_{0.1}$ load. In the latter case, corrosion was found to occur from the beginning, which increased initially up to a certain duration of ponding (Figure 6), beyond which the rate of corrosion was found to decrease. The use of GGBS in this case was found to delay modestly the onset of corrosion. These trends are further discussed below.
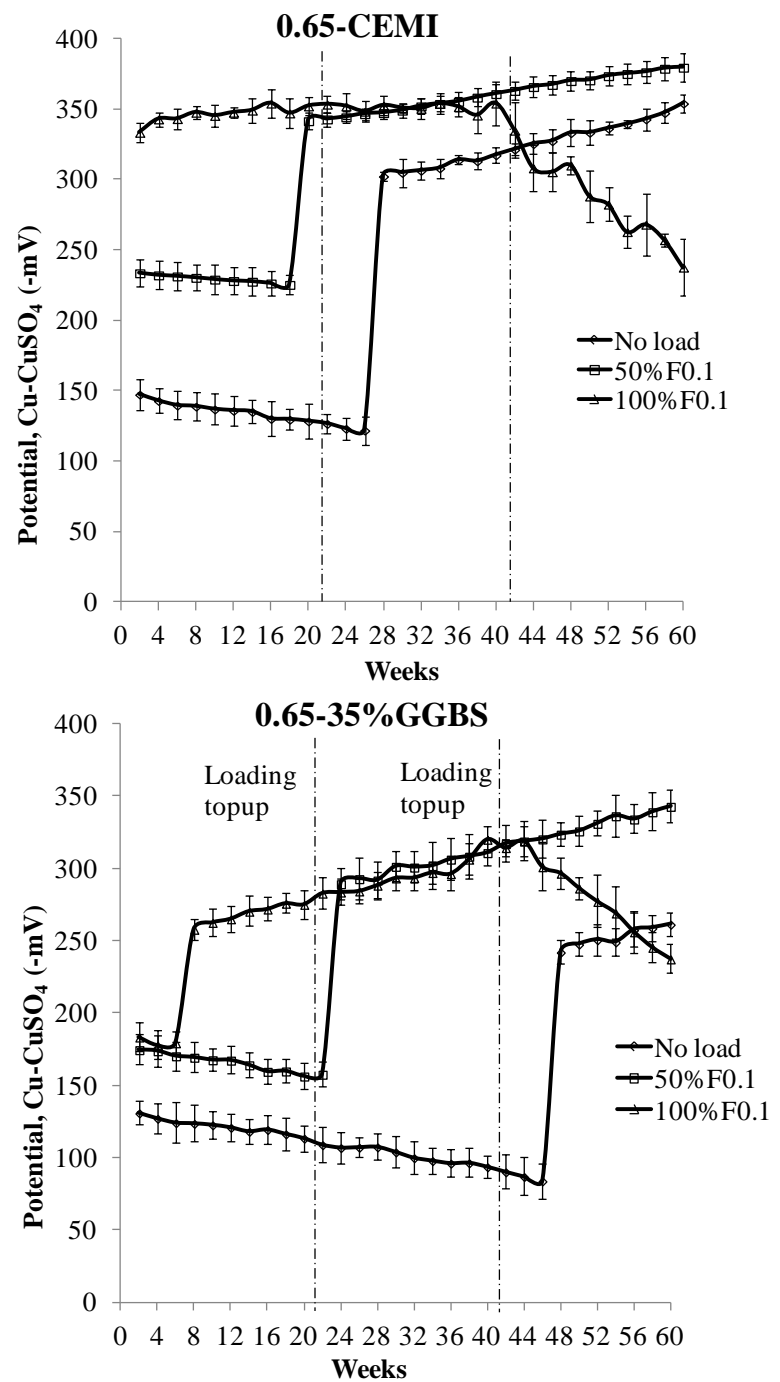
Figure 5 indicates a slight increase in half-cell potentials (less negative) with time for both unloaded and $50 \% \quad \mathrm{~F}_{0.1}$ load cases, presumably due to improvements in microstructure around the steel as a result of interactions between penetrating chlorides and hydrated cement phases. However, once the corrosion has initiated, the half-cell potentials decreased (more negative) sharply and they continue to do so during the remainder of the ponding period, indicating the propagation of corrosion. This trend was seen for all the four types of concrete mixes. As highlighted already, for CEMI beams subjected to $100 \%$ of $F_{0.1}$ load, the half-cell potentials decreased (more negative) continually from the beginning up to a point, beyond which there was an increase (less negative) for both 0.45 and $0.65 \mathrm{w} / \mathrm{cm}$ ratio. The use of GGBS was found to delay the onset of corrosion, but these beams also followed a trend similar to that of CEMI beyond this point.
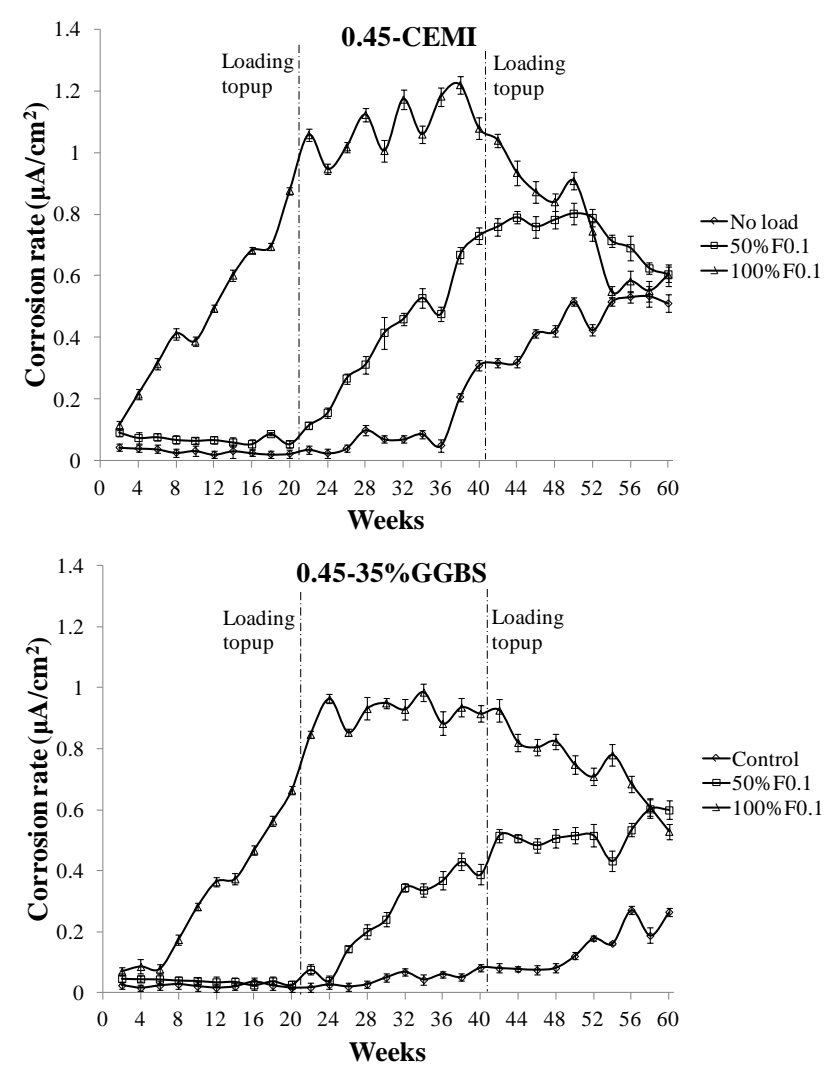

The data in Figure 6 confirm that where there was a sudden decrease in half-cell potentials (more negative) there was an associated increase in the rate of corrosion measured using the LPR test. When the two cementitious materials are compared, it can be seen that the use of GGBS resulted in a decrease in the rate of corrosion. It was also found that the rate of corrosion was higher when beams were subjected to increased levels of loading. The influence of watercementitious material ratio was found to delay the onset of corrosion, but not the rate of corrosion. Interestingly, there was a slight decrease in the rate of corrosion with duration of ponding for all the beams, although the half-cell potentials continued to decrease. The possible reasons for this decrease in corrosion are discussed separately.
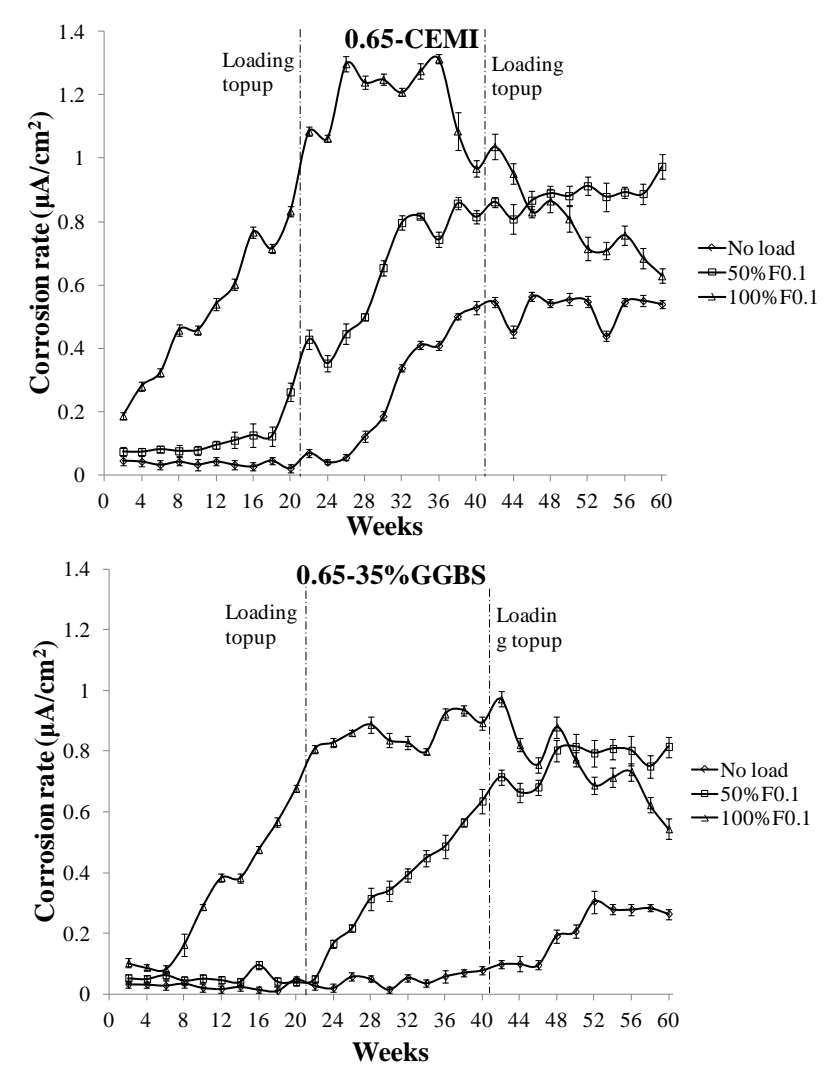

Figure 6. Temperature compensated corrosion rates.

In nutshell, it can be seen from Figures 5 and 6 that cracks induced at both $100 \%$ of $F_{0.1}$ load and $50 \%$ of $F_{0.1}$ load greatly accelerated both the initiation and propagation stages of the corrosion of steel in concrete beams. The time needed for corrosion initiation is summarised in Table 4. This table shows that the time needed for corrosion initiation in different beams was followed the trend of $100 \% \mathrm{~F}_{0.1}<50 \% \mathrm{~F}_{0.1}$ $<$ No loading. GGBS concretes had a better corrosion resistance compared with CEMI concretes. The time of corrosion initiation in GGBS beams is much longer than that in CEMI beams when they were under the same loading condition. These results confirm the benefit of using GGBS in concretes for structures 
exposed to cyclic chloride exposure at different loading conditions.

As stated already, there was a descending trend of corrosion rates in $100 \% \mathrm{~F}_{0.1}$ group of beams after a certain period of chloride exposure. Given that all these beams were saturated with chloride solution at the time of measurement, this cannot be assigned to the variations in moisture content. However, it has been demonstrated by Sahmaran (2007) and Otieno et al. (2010) that self-healing phenomenon of small cracks can improve the corrosion resistance with time. This effect could be seen in beams subjected to both levels of loading (Figure 6), though for beams that were not subjected to $50 \%$ of $\mathrm{F}_{0.1}$, the effect was smaller. This suggests that the self-healing effect of cracks in the two different groups of beams were different and the self-healing of small cracks in beams under $100 \% \mathrm{~F}_{0.1}$ was more effective than that in beams under $50 \% \mathrm{~F}_{0.1}$ load.

Table 4. Time to corrosion initiation (weeks).

\begin{tabular}{lllll}
\hline Load level & $\begin{array}{l}\mathbf{0 . 4 5 -} \\
\text { CEMI }\end{array}$ & $\begin{array}{l}\mathbf{0 . 4 5 -} \\
\text { 35\%GGBS }\end{array}$ & $\begin{array}{l}\mathbf{0 . 6 5 -} \\
\text { CEMI }\end{array}$ & $\begin{array}{l}\mathbf{0 . 6 5 -} \\
\text { 35\%GGBS }\end{array}$ \\
\hline No load & 36 & 48 & 28 & 46 \\
$50 \% \mathrm{~F}_{0.1}$ & 20 & 26 & 18 & 24 \\
$100 \% \mathrm{~F}_{0.1}$ & 0 & 6 & 0 & 6 \\
\hline
\end{tabular}

The differences in the self-healing effects of small cracks in beams under both $50 \%$ and $100 \%$ of $\mathrm{F}_{0.1}$ load may be explained by analysing the different damage degree in concretes in these two cases (Zhong and Yao, 2008). As shown in Figure 7, the concrete strain in the two different groups of beams can be calculated using Equation 4 (Philpot, 2012) and Equation 5.

$$
\begin{aligned}
& \varepsilon_{1}=\frac{L-L_{0}}{L_{0}} \\
& \varepsilon_{2}=\frac{L-w_{c r}-L_{0}}{L_{0}}
\end{aligned}
$$

where $\varepsilon_{1}$ and $\varepsilon_{2}$ are concrete strains on tension surfaces of beams $50 \% \mathrm{~F}_{0.1}$ and $100 \% \mathrm{~F}_{0.1}, L_{0}$ is the original distance between the two DEMEC studs, $L$ is the distance between the two DEMEC studs after the load was applied, $w_{c r}$ is the width of crack along the measured distance between the two DEMEC studs on beams with $100 \% \mathrm{~F}_{0.1}$ (if more than one crack existed, $w_{c r}$ is the accumulated crack width).

The results are reported in Table 5. Concrete strain in beams for the $100 \% \mathrm{~F}_{0.1}$ load was much smaller than that in beams under $50 \% \mathrm{~F}_{0.1}$ load. Therefore, the selfhealing effect influenced at a greater extent for the $100 \% \mathrm{~F}_{0.1}$ load cases.
Table 5. Concrete strain $\left(10^{-6}\right)$.

\begin{tabular}{lllll}
\hline Load level & $\begin{array}{l}\mathbf{0 . 4 5 -} \\
\text { CEMI }\end{array}$ & $\begin{array}{l}\text { 0.45- } \\
\text { 35\%GGBS }\end{array}$ & $\begin{array}{l}\mathbf{0 . 6 5 -} \\
\text { CEMI }\end{array}$ & $\begin{array}{l}\text { 0.65- } \\
\text { 35\%GGBS }\end{array}$ \\
\hline $50 \% \mathrm{~F}_{0.1}$ & 508 & 390 & 498 & 463 \\
$\begin{array}{l}100 \% \mathrm{~F}_{0.1} \\
\text { (for the }\end{array}$ & 72 & 64 & 61 & 64 \\
$\begin{array}{l}\text { uncracked } \\
\text { part) }\end{array}$ & & & & \\
\hline
\end{tabular}
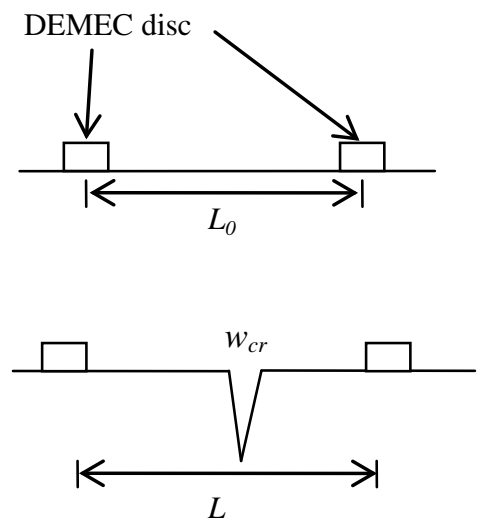

Figure 7. Parameters used for the calculation of concrete strain.

\section{CONCLUSIONS}

On the basis of results reported and discussed in this paper, the following conclusions have been made:

- Structural cracks caused by the application of transverse loading of intensity that is permitted in Eurocode 2 for marine structures were found to admit large quantities of chlorides at the cracked region of beams. At lower load levels, the quantity of chlorides penetrated into concrete depended on the intensity of the applied loads. The benefit of using a lower water-cementitious material ratio and GGBS in such cases was to reduce the penetration of chlorides.

- Beams subjected to higher load levels had shorter time to initiation of corrosion, higher corrosion potentials and higher corrosion rates. The use of a lower water-cementitious material ratio and GGBS resulted in a decrease in the corrosion initiation time, but the rate of corrosion was not noticeably influenced.

- Due to the less damage inside the concrete of $100 \% F_{0.1}$ beams, the self-healing effect of cracks in $100 \% \mathrm{~F}_{0.1}$ beams was considered to be more effective than that in $50 \% \mathrm{~F}_{0.1}$ beams, which was found to decrease the corrosion rate after a certain period of exposure.

These findings suggest that the effect of microcracking on the corrosion of steel in concrete might be more important than macro-cracks when considering for 
durability design of reinforced concrete structures in chloride exposure environments.

\section{REFERENCES}

ASTM. (1999). ASTM Standard C876-91 (reapproved 1999) Test Method for Corrosion Potentials of Uncoated Reinforcing Steel in Concrete.

Bamforth, P. (2004). Enhancing reinforced concrete durability: Part two: Supplementary Technical Reports. Concrete Soceity Technical Report 61, Concrete Society.

Basheer, P., Chidiac, S., \& Long, A. (1996). Predictive models for deterioration of concrete structures. Construction and Building Materials, 10(1), 27-37.

British Standards Institution. (1989). BS 1881125:1986, Testing concrete-Part 125: Methods for mixing and sampling fresh concrete in the laboratory.

British Standards Institution. (1992). BS 882-1992 Specification for aggregates from natural sources for concrete.

British Standards Institution. (1992). BS 6699:1992 Specification for ground granulated blastfurnace slag for use with Portland cement.

British Standards Institution. (2011a). BS EN 1992-11:2004, Eurocode 2: Design of concrete structures-Part 1-1: General rules and rules for buildings.

British Standards Institution. (2011b). BS EN 1971:2011, Cement Part 1: Composition, specifications and conformity criteria for common cements.

British Standards Institution. (2012). BS 8500-12006+A1-2012 Concrete. Complementary British Standard to BS EN 206-1. Method of specifying and guidance for the specifier.

Brett, C. M. A., \& Brett, A. M. O. (1993). Electrochemistry principles, methods, and applications. Oxford University Press.

Konin, A., Francois, R., \& Arliguie, G. (1998). Penetration of chlorides in relation to the microcracking state into reinforced ordinary and high strength concrete. Materials and Structures, 31(5), 310-316.

$\mathrm{Li}, \mathrm{C}$. (2000). Corrosion initiation of reinforcing steel in concrete under natural salt spray and service loading-Results and analysis. ACl Materials Journal, 97(6), 690-697.

Li, G., Hu, F., \& Wu, Y. (2011). Chloride ion penetration in stressed concrete. Journal of Materials in Civil Engineering,23(8), 1145-1153.

Liu, Y. (1996). Modeling the time-to-corrosion cracking of the cover concrete in chloride contaminated reinforced concrete structures (Doctoral dissertation). Virginia Polytechnic Institute and State University, Blacksburg, Virginia, Citeseer.

Mehta, P. K., \& Monteiro, P. J. M. (2006). "Microstructure and properties of hardened concrete." Concrete: microstructure, properties and materials (3rd ed.). New York: McGraw-Hill, 41-80.

Mohammed, T. U., Otsuki, N., Hisada, M., \& Shibata, T. (2001). Effect of crack width and bar types on corrosion of steel in concrete. Journal of Materials in Civil Engineering,13(3), 194-201.

Otieno, M., Alexander, M., \& Beushausen, H. (2008). Corrosion propagation in cracked and uncracked concrete. Concrete Repair, Rehabilitation and Retrofitting: 2nd International Conference on Concrete Repair, Rehabilitation and Retrofitting, ICCRRR-2CRC,157.

Otieno, M., Alexander, M., \& Beushausen, H. (2010). Corrosion in cracked and uncracked concreteinfluence of crack width, concrete quality and crack reopening. Magazine of Concrete Research, vol. 62(6), 393-404.

Philpot, T. A. (2012). Mechanics of Materials: An Integrated Learning System (3rd ed.). New York: John Wiley \& Sons, p. 891.

Rodriguez, O. G., \& Hooton, R. D. (2003). Influence of cracks on chloride ingress into concrete. $\mathrm{ACl}$ Materials Journal, 100(2).

Sahmaran, M. (2007). Effect of flexure induced transverse crack and self-healing on chloride diffusivity of reinforced mortar. Journal of Materials Science, 42(22), 9131-9136.

Sahmaran, M., \& Yaman, I. Ö. (2008). Influence of transverse crack width on reinforcement corrosion initiation and propagation in mortar beams. Canadian Journal of Civil Engineering, 35(3), 236245.

Sangoju, B., Gettu, R., Bharatkumar, B. H., \& Neelamegam, M. (2011). Chloride-induced corrosion of steel in cracked OPC and PPC concretes: Experimental study. Journal of Materials in Civil Engineering, 23(7), 1057-1066.

Schiessl, P., \& Raupach, M. (1997). Laboratory studies and calculations on the influence of crack width on chloride-induced corrosion of steel in concrete. $\mathrm{ACl}$ Materials Journal, 94(1), 56-62.

Siemes, T., \& Edvardsen, C. (1999). Duracrete: Service life design for concrete structures. Presented at the Eighth International Conference on Durability of Building Materials and Components, 8DBMC. pp. 1343-1356.

Thomas, M., \& Bentz, E. (2001). LIFE-365, Service life prediction model, computer program for predicting the service life and life-cycle costs of reinforced concrete exposed to chlorides. University of Toronto.

Violetta, B. (2002). Life-365 service life prediction model. Concrete International, 24(12), 53-57.

Wang, H., Lu, C., Jin, W., \& Bai, Y. (2011). Effect of external loads on the Chloride transport in concrete. Journal of Materials in Civil Engineering, 23(7), 1043-1049. 
Wang, Y., Lin, C., \& Cui, Y. (2014). Experiments of Chloride ingression in loaded concrete members under the Marine environment. Journal of Materials in Civil Engineering, 26(6). 04014012.

Zhong, W., \& Yao, W. (2008). Influence of damage degree on self-healing of concrete. Construction and Building Materials, 22(6), 1137-1142. 